\title{
Introduction: The Archaeology of Jesuit Sites in the Americas
}

\author{
Stephan T. Lenik \\ Department of Anthropology, St. Mary's College of Maryland, St. Mary's \\ City, MD, USA \\ stlenik@smcm.edu \\ Laura E. Masur \\ Department of Anthropology, Catholic University, Washington, DC, USA \\ masur@cua.edu
}

\begin{abstract}
The archaeological record of Jesuit sites in the Americas preserves an essential resource for the study of daily life among individuals in the Jesuit sphere of influence. The full potential of an archaeological synthesis of these sites has yet to be realized, since systematic excavations have occurred at only a relatively small number of Jesuit sites in the American continents and the Caribbean. This essay serves to introduce a collection of five archaeological case studies and a conclusion, which show how archaeology complements the written histories of Jesuits from Nasca to New France. These case studies address several major themes, including the definition of mission sites, scales of analysis, the nature of missionary "success," and overcoming historical silences. In particular, they articulate the influence of Jesuit missionaries on the material worlds of numerous cosmopolitan communities of colonists, enslaved Africans, and American Indians.
\end{abstract}

\section{Keywords}

Society of Jesus - Jesuit - mission - plantation - historical archaeology - the Americas - enslaved Africans - American Indians - colonialism 


\section{Introduction}

The archaeological record offers a more comprehensive and exacting account of the impact of the Society of Jesus in the Americas by uncovering evidence of daily life that is not recoverable through other means. The full potential of such an endeavor has yet to be realized, since systematic excavations have occurred at only a relatively small number of Jesuit missions, haciendas, plantations, farms, colleges, and other properties in the American continents and in the Caribbean. Moreover, there has not been, to the best of our knowledge, a concerted effort to synthesize what has been found, and few previous scholarly works have explicitly attempted to integrate archaeology into the field of Jesuit studies. ${ }^{1}$ To account for these limitations, this special issue entitled "The Archaeology of Jesuit Sites in the Americas" begins to identify major themes of already completed and ongoing research. Framing the collection in this manner, as the archaeology of "Jesuit sites" rather than "Jesuit missions," captures the broad variety of activities that fall within the overall category of "mission" and which form the archaeological record in the Americas.

The case studies that are collected in this issue, along with other examples cited below, show how archaeology can complement written histories of Christian mission sites and approach topics that are not addressed in the documents. These histories rely on documents produced by Catholic religious orders and Protestant groups that embarked upon global evangelizing activities, as well as the state jurisdictions in which missions operated. ${ }^{2}$ For the Society of Jesus, an extensive written record reveals primarily the perspectives of Jesuit personnel that produced these accounts, whereas the experiences of peoples of Indigenous and African ancestry appear only on the margins, if at all. In other cases, written life histories of Indigenous persons were the creation of the missionaries themselves. ${ }^{3}$ Oral traditions should also be considered

$1 \quad$ But see Victor M. Fernández et al., The Archaeology of the Jesuit Missions in Ethiopia (15571632) (Leiden: Brill, 2017).

2 Willem Boshoff, "Global Conversions: The Archaeology of Missionary Engagements," Missionalia 32, no. 3 (2004): 309-12; Elizabeth Graham, "Mission Archaeology," Annual Review of Anthropology 27 (1998): 25-62; Jerald T. Milanich, Laboring in the Fields of the Lord: Spanish Missions and Southeastern Indians (Washington, DC: Smithsonian Institution Press, 1999); Lee M. Panich, "Mission Archaeology in North America," in Encyclopedia of Global Archaeology, 2nd ed., ed. Claire Smith (New York: Springer-Verlag, 2018), doi:10.10o7/978-3-319-51726-1_1396-2.

3 Kay I. Koppedrayer, "The Making of the First Iroquois Virgin: Early Jesuit Biographies of the Blessed Kateri Tekakwitha," Ethnohistory 40, no. 2 (1993): 277-306, here 28o. 
as part of this record, on behalf of many communities that remain Catholic today because of past Jesuit missions.

Even more important is the opportunity to draw from the material record to critically examine the impact of the Jesuits since the sixteenth century. This record may originate with archaeological excavations, which is our primary area of concern in this issue, but also with data that come from studies of objects in museum collections as well as analyses of written accounts of material culture, buildings, and other permanent features associated with the Jesuit order. Thus, an anthropological historical archaeology that is directed toward the study of Jesuit sites represents more than a mere "handmaiden to history" to supplement and illustrate the documents. ${ }^{4}$ Rather, it provides an unparalleled record of daily life in the Jesuit sphere of influence, through which to ask anthropological questions about culture, economy, and the supernatural, based on the fragmentary material remains recovered through systematic excavations. ${ }^{5}$ These data and the interpretations that result may correlate with documents and oral traditions, but they also may clash with those sources, an occurrence that is well-known to historical archaeologists. Even for the Society of Jesus, which produced a voluminous archive that has been stored at the Archivum Romanum Societatis Iesu and various satellite repositories since 1540, not everything was written down. Furthermore, some accounts were biased or inaccurately recorded, whereas other aspects of life were not deemed of sufficient importance to write down. As well, Jesuit writings about spirituality pertain to the immaterial aspects of human existence, mentioning the mundane material elements of everyday life ("temporalities") only as they related to spirituality or finances. One of the strengths of archaeology in general, and an archaeology of Jesuit sites in particular, is that it gains access to portable sacred objects or structural remains that individuals within the mission sphere would have noted, but that it also accesses a material record of the implicit or apparently unimportant past cultural practices that escaped notice-the "small things forgotten" in the words of archaeologist James Deetz. ${ }^{6}$

4 Jean Carl Harrington, "Archaeology as an Auxiliary Science to American History," American Anthropologist 57, no. 6 (1955): 1121-3o.

5 Dan Hicks and Mary Beaudry, eds., The Cambridge Companion to Historical Archaeology (Cambridge: Cambridge University Press, 2006); Charles E. Orser, Jr., Historical Archaeology, 3 rd ed. (New York, NY: Routledge, 2017).

6 James Deetz, In Small Things Forgotten: An Archaeology of Early American Life (New York: Anchor Books, Doubleday, 1996). 


\section{Placing this Collection in Context}

This special issue reveals how archaeology is a critical but under-utilized resource in Jesuit studies. The five case studies and conclusion provide different perspectives of reflection and critique, contributing new data that are suitable for investigating questions that are not answerable based on written documents alone. Additionally, this collection moves toward a broader synthesis of past archaeological research at Jesuit sites in the Americas. Ideally, this effort should occur in conversation with specialists in Jesuit studies, and so Journal of Jesuit Studies is the perfect venue. As we learned when the original versions of these papers were presented in 2019 at the annual Society for Historical Archaeology conference in St. Charles, Missouri, many archaeologists who have investigated Jesuit sites are interested in the important but challenging tasks of comparison and synthesis.

At this juncture, it is important to acknowledge that this issue represents a starting point that may reveal paths for future research. Through organizing the original conference session and developing this special issue, our aim is not to achieve full geographical or temporal coverage of the Jesuits in the Americas, nor is it to attempt a global perspective, a point that we address below. Certainly, there are gaps in this collection that are open to future scholarly research. As a result, comparisons to archaeological findings, material culture studies, or the historical record of Jesuit activities in Europe, Africa, and Asia, are not fully explored. ${ }^{7}$ Moreover, our focus on the Americas does not consider recent archaeological research on other continents, like the Jesuit mission to Ethiopia. ${ }^{8}$ Interestingly, the Jesuits themselves were the earliest archaeologists at several Jesuit sites mentioned in this issue, and more broadly in American historical archaeology. For example, in the 193os, Jesuit scholastics vacationing at St. Inigoes Manor in Maryland identified and excavated buried remains of the eighteenth-century mission-plantation, and the Jesuit Félix Martín (1804-86) excavated the Ste. Marie I mission site in $1855 .{ }^{9}$ Nonetheless, this Jesuit involvement in archaeology will have to be examined elsewhere.

7 The promise of this kind of approach that might be applied to the archaeology of Jesuit sites, or material culture associated with the Society of Jesus, is shown in recent work, such as Jorge Cañizares-Esguerra, Robert Aleksander Maryks, and Ronnie Po-chia Hsia, eds., Encounters between Jesuits and Protestants in Asia and the Americas (Chestnut Hill, MA: Institute for Advanced Jesuit Studies, Boston College/ Leiden: Brill, 2018).

8 Fernández et al., Archaeology of the Jesuit Missions in Ethiopia.

9 "Interesting Items from Saint Inigoes," Woodstock Letters 62, no. 3 (1933): 359-64. Orser, Historical Archaeology, 29-31. 
With the above qualifications in mind, we ask why American archaeology has remained largely absent from the rapidly growing field of Jesuit studies. ${ }^{10}$ Among the main obstacles is that only a few sites in the Americas have seen multi-year investigations by archaeologists adhering to consistent research designs that are attuned to the Jesuit presence. Two examples of these sustained projects are represented here, in the papers by Réginald Auger and coauthors about Habitation Loyola in French Guiana, and by José António Brandão and Michael Nassaney for Fort St. Joseph in Michigan. Missing from the present issue is coverage of the extensive architectural and archaeological studies of the reductions in Paraguay, Argentina, and Brazil, and it is unfortunate that there is not a stronger representation of that work here. ${ }^{11}$ Literature about Jesuit site archaeology is scattered across articles and book chapters, some of which are easy to find, yet a wealth of information is buried in site reports, dissertations, theses, and other so-called gray literature, not to mention artifacts collections that have seen only limited study. It should also be noted that a review of archaeological work related to Jesuits in the Americas

10 John W. O'Malley, "Past, Present, and Future of Jesuit Studies: Historiographical Thoughts," Journal of Jesuit Studies 5, no. 4 (2018): 501-10, doi:10.1163/22141332-005040o1. Note the absence of the field of archaeology in John W. O'Malley et al., eds., The Jesuits: Cultures, Sciences, and the Arts, 1540-1773 (Toronto: University of Toronto Press, 1999); John W. O'Malley et al., eds., The Jesuits II: Cultures, Sciences, and the Arts, 1540-1773 (Toronto: University of Toronto Press, 2006).

11 Many places where Jesuits were active in Mexico and Central and South America have also been examined by archaeologists but are not represented in this collection. Among the few English language sources are Clement James McNaspy, "The Archaeology of the Paraguay Reductions (1609-1767)," World Archaeology 18, no. 3 (1987): 398-410; Evelyn R. Nimmo, "Approaching Archaeological Museum Collections through the Concept of Assemblage: The Case Study of the Jesuit Mission San Ignacio Miní (1610-1631)," Latin American Antiquity 31, no. 3 (2020): 615-31; María Victoria Roca, "Archaeology, Heritage, and Development in Two South American Colonial Sites: The Guarani-Jesuit Missions (1610-1767)," in Collision or Collaboration: Archaeology Encounters Economic Development, ed. Peter Gould and K. Anne Pyburn (Cham, Switzerland: Springer International Publishing, 2017), 117-35. There are many publications in Spanish covering the archaeology and restoration work in South America, notable examples include Arno Alvarez Kern, ed., Arqueología histórica missioneira (Porto Alegre: EDIPUCRS, 1998); María Victoria Roca, "Arqueología de las misiones jesuíticas guaraníes en Argentina: Estado de situación," Folia histórica del Nordeste 35 (2019): 121-44; Amanda E. Ocampo et al., "Aportes a la arqueología reduccional: El caso de Nuestra Señora de Ibitiracuá (Concepción de la Sierra, Misiones, Argentina)," Arqueología 25, no. 2 (2019): 235-46; Ruth A. Poujade and Lorena Salvatelli, "Puesta en valor de la reducción jesuítica guaraní: Nuestra Señora de Loreto, Misiones, Argentina," Revista teoría y práctica de la arqueología histórica latinoamericana 3 (2014): 73-84; Maria Matilde Villegas Jaramillo, "Protección del patrimonio cultural de las misiones jesuíticas de los Guaraní: Intervenciones en los sitios arqueológicos misioneros de Sáo Joáo Batista y Sáo Lourenco Mártir," Apuntes: Revista de estudios sobre patrimonio cultural 19, no. 1 (2006): 98-113. 
faces the obstacle of linguistic boundaries, requiring at least a reading knowledge of English, Spanish, French, Portuguese, and Latin, to fully access the numerous site reports, publications, and archival sources. All of these factors contribute to the dearth of sustained analysis. Many of the shorter site-specific studies, in regions like Maryland or New France, have emerged in a somewhat piecemeal fashion without an overarching research design. While attempts at regional synthesis - including several in this issue-compare spatial patterns or specific artifact types, for instance, a hemispheric or global sense of the archaeology of Jesuit sites has not emerged. This contrasts with the increasingly global, comparative scope of Jesuit studies that has flourished in the last several years. ${ }^{12}$ Consequently, the case studies from Guiana, Peru, Maryland, Michigan, and Vermont that are presented here represent early scholarly considerations of the global material presence of the Society of Jesus. We anticipate that this issue may inspire future comparative research, which draws on archaeological sites across multiple regions and time periods.

\section{Themes of the Issue}

This introductory essay has two aims. First, as a brief summation of the papers it identifies the major themes appearing in the articles that follow, in order to contribute new questions and insights to ongoing conversations in Jesuit studies. This will begin to bring into focus the current state of the archaeology of Jesuit sites in the Americas, and reveal points of articulation and potential areas of disjuncture that may exist between the archaeology of Jesuit sites and the field of Jesuit studies. We have asked authors to briefly explain archaeological field methods when appropriate, with the expectation that readers may not be well-versed in archaeological theory and method. Second, this essay urges a more explicit, broadly conceived consideration of the Jesuit presence in the material world, by emphasizing how archaeology preserves evidence of the daily lives of the array of people who were pulled into the Jesuit sphere. While sacred artifacts or religious structures like churches are clearly interesting to

12 Luke Clossey, Salvation and Globalization in the Early Jesuit Missions (New York: Cambridge University Press, 2008); Thomas M. Cohen and Emanuele Colombo, "Jesuit Missions," in The Oxford Handbook of Early Modern European History, 1350-1750, Volume II: Cultures and Power, ed. Hamish Scott (Oxford: Oxford University Press, 2015), 2:254-79; Girolamo Imbruglia, "A Peculiar Idea of Empire: Missions and Missionaries of the Society of Jesus in Early Modern History," in Jesuit Accounts of the Colonial Americas: Intercultural Transfers Intellectual Disputes, and Textualities, ed. Marc André Bernier, Clorinda Donato, and Hans-Jürgen Lüsebrink (Toronto: University of Toronto Press, 2014), 21-49. 
archaeologists and worthy of study, focusing solely on the numinous is insufficient. This point becomes clear when considering the contexts that archaeologists have examined at Jesuit sites in the Americas, and the types of artifacts and features that are typically recovered and documented..$^{13}$ Moreover, the Society of Jesus possesses distinctive features that derive from its spirituality and hierarchical administrative structure, for example, though the extent to which this distinctiveness appears archaeologically remains poorly understood.

The varied nature of Jesuit activities in the Americas that is apparent in the issue would explain the title's focus on sites rather than missions, as explained earlier. At Fort St. Joseph in Michigan, a multi-purpose settlement that included a fort, garrison, domestic areas, and a trading post, José António Brandão and Michael Nassaney critically examine the documentary and archaeological evidence of French Jesuits among French colonists and Native peoples to consider the success of the mission. ${ }^{14}$ Andrew Beaupré's contribution explores evidence of French Jesuit ministry in Abenaki villages and mission outposts, and its effect on Indigenous sovereignty in present-day Vermont. Laura Masur's paper about English Jesuits in Maryland shows how archaeological evidence illustrates otherwise poorly understood interactions among Jesuits, American Indians, and African Americans. These three examples exhibit variation in Jesuit missions that depart from the model of the reduction mission..$^{15}$ Reductions (reducciones) were settlements in which one or more Indigenous groups were brought to live in a sedentary location, under the watchful eye of Jesuits. The best-known examples (mentioned earlier) are from modern-day Paraguay, Brazil, and Argentina. ${ }^{16}$ Archaeologists have yet to address how the presence of Jesuits-in Native villages, mission outposts,

13 For archaeologists, in this sense "features" are non-portable evidence of human activity, such as architectural remains.

14 In addition to the essay found here, a synthesis of research at Fort St. Joseph can be found in Michael S. Nassaney, ed., Fort St. Joseph Revealed: The Historical Archaeology of a Fur Trading Post (Gainesville: University Press of Florida, 2019).

15 A recent archaeological example illustrating the variable nature of Jesuit mission sites includes Fort San Antón, dating from 1567-69, at Mound Key in Florida. See Victor D. Thompson et al., "Discovering San Antón de Carlos: The Sixteenth-Century Spanish Buildings and Fortifications of Mound Key, Capital of the Calusa," Historical Archaeology 54, no. 2 (2020): 334-53.

16 Imbruglia, "Peculiar Idea of Empire," 21; Thomas O'Brien, "Utopia in the Midst of Oppression?: A Reconsideration of Guaraní/ Jesuit Communities in Seventeenth- and Eighteenth-Century Paraguay, Contemporary Justice Review 7, no. 4 (2004): 395-410, here 397. McNaspy, "Archaeology of the Paraguay Reductions"; Roca, "Archaeology, Heritage, and Development”; Robert M. Weaver, "The Jesuit Reduction System Concept: Its Implications for Northwest Archaeology," Northwest Anthropological Research Notes 11, no. 2 (1977): 163-73. 
or reductions-negatively impacted the lives of Indigenous people in the Americas through shifts in diet, labor practices, or exposure to disease. ${ }^{17}$

The remaining papers reflect Jesuit involvement in owning and operating plantations that were reliant upon enslaved African labor. In some places, such as French Guiana, the proceeds funded evangelization among Indigenous Americans, whereas in locales like Louisiana and French Caribbean island colonies and frontiers, these plantations supported missions among the colonists and the enslaved African population. ${ }^{18}$ The paper by Réginald Auger and co-authors about Habitation Loyola in French Guiana, with more than twenty-five years of archaeology resulting in numerous publications and reports, is a fine-grained study of a Jesuit plantation that funded their mission work. Habitation Loyola symbolized temporal and spiritual authority through human transformation of the environment, in effect cementing the Jesuits' social station within colonial Guiana. ${ }^{19}$ Brendan Weaver's comparative study of two Spanish Jesuit haciendas in Peru reveals the material and textual traces of how the diverse, cosmopolitan community of enslaved African laborers negotiated the Jesuit strategies of labor as Christian discipline. Like Indigenous peoples at mission sites, enslaved individuals on the Jesuits' plantations undoubtedly encountered both physical and social violence in their everyday lives. ${ }^{20}$ But with the exception of Weaver's research, an archaeology of Jesuit sites heretofore provides an inadequate understanding of enslaved life, since there have yet to be household-level investigations of the lives of enslaved laborers at Jesuit-owned plantations. The following sections introduce four major themes of the issue: the definition of mission sites, scales of analysis, the nature of missionary "success," and overcoming historical silences.

17 These are common themes for archaeological investigations of Spanish missions in the Americas. See Panich, "Mission Archaeology."

18 Stephan Lenik, "Frontier Landscapes, Missions, and Power: A French Jesuit Plantation and Church at Grand Bay, Dominica (1747-1763)" (unpublished PhD diss., Syracuse University, 2010); Lenik, "Mission Plantations, Space, and Social Control: Jesuits as Planters in French Caribbean Colonies and Frontiers," Journal of Social Archaeology 12, no. 1 (2012): 41-61.

19 See also Yannick Le Roux, Réginald Auger, and Nathalie Cazelles, Les Jésuites et l'esclavage: Loyola, l'habitation des jésuites de rémire en Guyane française (Quebec: Presses de l'Université du Québec, 2009).

20 See Adam Rothman, ed., "The Jesuits and Slavery," Journal of Jesuit Studies 8, no. 1 (2021): 1-107, https://doi.org/10.1163/22141332-0801Pool. Regarding the issue of violence among Africans enslaved by the Jesuits, see Andrew Dial, "Antoine Lavalette, Slave Murderer: A Forgotten Scandal of the French West Indies," Journal of Jesuit Studies 8, no. 1 (2021): 37-55, doi:10.1163/22141332-0801Poo3. 


\section{Defining the Jesuit Mission}

Mission outposts, in whatever form they assumed, were one of the major loci of sustained encounter among Jesuits and Indigenous peoples, and to a lesser extent, enslaved Africans. The articles in this collection emphasize this point, one that is vital to understanding the scope of Jesuit activities in the Americas. Yet, limiting our discussion to traditionally defined mission sites fails to encompass the broad variety of Jesuit activities that have formed the archaeological record in the Americas. In part, the special issue's title captures this heterogeneity by referencing the "archaeology of Jesuit sites," rather than the "archaeology of Jesuit missions," with the former yielding a more broadly conceived account of activities occurring under the purview of the Society of Jesus. In addition, the notion of site is grounded in the practice of archaeology in which a site is an analytical unit; it is, at least in theory, a static and spatially delineated resource. Even the basic concepts of sites like mission or plantation, as they pertain to archaeology, deserve some reevaluation, as Masur's paper argues.

Archaeology can lend insight into Jesuit strategies, goals, and management styles in order to account for material manifestations of this variability within the overarching category of mission. We ask, what were the Jesuits trying to accomplish, and what does the archaeological record reveal about their tangible strategies for achieving these goals? Each paper, in one way or another, shows how archaeologists define a chronology, determine the precise positioning of structures or identify modifications that were made over time, and then establish their relationships to other aspects of the built and natural landscape. These details can help to reveal what the Jesuits were doing when organizing a site's spatial layout, or supplying it with building materials, objects for everyday use, or religious-themed items. Archaeology also pinpoints activities that occurred inside and around the mission by plotting artifact distributions, which reconstruct the spatial dimension of past behaviors that may not show up in the documentary record, especially for the Indigenous or enslaved persons who inhabited or visited Jesuit sites.

The heterogeneity of Jesuit sites also reflects a flexible "way of proceeding" that was particular to the Society of Jesus among Roman Catholic religious orders. Jesuits adapted, or accommodated, to varied environmental and cultural contexts, to include sites such as haciendas, forts, trading posts, plantations, and Native villages. Archaeology forces us to think about these sites and their functions in different ways, via the material record and from a diachronic perspective. Further, we ask whether there is anything distinctively "Jesuit" about the objects, structures, and patterns observed in the material record, through architecture or religious artifacts. 


\section{Navigating Scales of Analysis}

This leads to a second point that is relevant to the study of Jesuit sites- - how to determine the scale at which to analyze strategies and management styles. As agents of the Catholic Church, the Jesuits envisioned a universal domination, a global achievement of "Christendom," in reference to God's universal empire as a "sanctified enclave" that pushes outward to eventually incorporate all of humanity. ${ }^{21}$ Certainly, some common aspects were derived from the Spiritual Exercises and other core documents that formed Jesuit spirituality, as well as common religious symbols like the cross, the Sacred Heart of Jesus, or the Virgin Mary, all united through an administrative structure based in Rome. Connections between theological ideas and material objects or places should ostensibly provide common features that may manifest in some material form. But, as mentioned above, the Jesuits celebrated their unique "way of proceeding" by immersing themselves in the particularities of social, political, economic, and religious life. Historians of the Jesuits recognize the problems inherent in moving between analytical scales. ${ }^{22}$

For the archaeology of Jesuit sites, scale presents different and unique challenges. Archaeologists can consult core tenets of Jesuit beliefs to interpret architectural features of churches and cemeteries, and sacred objects like a medallion or cilice. The studies that follow illustrate different approaches to scale. The contributions by Auger and co-authors at Habitation Loyola, and Brandão and Nassaney at Fort St. Joseph, show the depth of insight that can be achieved by committed multi-year studies, which uncover Jesuit strategies in controlling nature and attending to the conversions at a multi-faceted outpost. Adopting a wider scope is Weaver's comparative study of haciendas in Peru, and Masur's study of several Jesuit plantations in Maryland and Pennsylvania. A still broader perspective comes from Beauprés account of how eighteenth-century Jesuit missions in Vermont resonate in the twenty-first century among Native Americans.

21 Allan Greer and Kenneth Mills, "A Catholic Atlantic," in The Atlantic in Global History $1500-$ 200o, ed. Jorge Cañizares-Esguerra and Erik R. Seeman (Upper Saddle River, NJ: Pearson Prentice Hall, 2007), 3-19; also Imbruglia, "Peculiar Idea of Empire," 23.

22 Takao Abé, "The Missionary Réductions in New France: An Epistemological Problem with a Popular Historical Theory," French Colonial History 15 (2014): 111-33; Clossey, Salvation and Globalization; Cohen and Colombo, "Jesuit Missions," 254-79. 


\section{Accounting for Success and Failure}

A third theme concerns the role of historical archaeology in determining whether a mission can be considered a "success." In this vein, this collection concentrates on the extent to which conversion, and ultimately salvation, was achieved. Archaeologically, documents and the material record reveal both the minutiae and the broader patterns that impacted the lives of people of Indigenous or African ancestry who became entangled in the Jesuit sphere. All of the authors address the presence of portable religious objects that appear in the archaeological record, and whether these provide a measure of successful conversion to and sustained practice of Catholicism. These types of finds exemplify the benefits of archaeological reconnaissance and excavation, particularly when seeking evidence of Roman Catholic belief and practice.

In reality, the interpretation of these objects is not always straightforward, as seen in the examples of the rosary beads discussed by Weaver, a cilice, beads, and other objects from Fort St. Joseph cited by Brandão and Nassaney, religious medallions and rosary-like objects referenced in Masur's article, and the so-called Jesuit rings discussed by Beaupré and found in many contexts in North America. ${ }^{23}$ Yet, it is difficult to establish a clear and unambiguous interpretation of these artifacts, especially, considering the nature of their exchange between practitioners of diverse cultural and faith traditions. There may often have been disjuncture between their traditional or documented meanings, and the beliefs of the person(s) who owned or had access to them. ${ }^{24}$ Any discussion of these artifacts must also address the limitations of archaeological interpretation.

Also deeply intertwined with the question of "success" or "failure" is the extent to which Jesuits functioned as agents of conversion or of colonialism. Each of these contributions addresses a different aspect of how the Jesuits intersected with colonialism. Brandão and Nassaney illustrate how a French Jesuit mission overlapped with economic, military, and domestic functions of Fort St. Joseph in Michigan, while Masur's paper describes the multifaceted role of Maryland plantations, which provided economic, political, and religious benefits and enabled the mission to persevere despite conflict with

23 Caroline Mercier, “Jesuit' Rings in Trade Exchanges between France and New France: Contribution of a Technological Typology to Identifying Supply and Distribution Networks," Northeast Historical Archaeology 40, no. 1 (2011): 21-42.

24 Laura E. Masur, "Symbol or Presence?: Archaeology and the Materiality of Catholic Devotions," U.S. Catholic Historian 38, no. 2 (2020): 1-21. 
colonial governments. Weaver's study of Jesuit haciendas in Peru and Auger and coauthors' article on Habitation Loyola in Guiana show how Jesuit agricultural properties existed alongside secular estates that were subjected to colonial laws and benefitted colonial administrators. Beauprés paper addresses the long-term effects of colonialism on Indigenous nations, who use evidence of missions in order to regain their sovereignty.

\section{Silencing of the Past}

A fourth theme returns to the observation made at the start of this essay concerning the absence of a sustained conversation between historical archaeologists who have studied Jesuit sites and the field of Jesuit studies. This consists of two parts. First, where do Jesuit sites fit in terms of historical archaeological literature? Second, how do projects address archaeological ethics, namely consultation and collaboration with descendant and stakeholder groups?

Jesuit missions do not feature in American archaeological literature in a way that compares to Spanish Franciscan missions, where important historical archaeology has taken place since the 196os. Elizabeth Graham's seminal article on "Mission Archaeology" only briefly mentions Jesuits, instead focusing largely on the work of Franciscans and Dominicans in the Spanish colonies, as is also the case for a more recent review by Lee Panich. ${ }^{25}$ We must ask why a synthesis of research has not happened earlier for the Jesuits, as it did for other Catholic religious orders. ${ }^{26}$ As well, what, if any, is the best-known "Jesuit site" that historical archaeologists can reference? Although South American reductions have been studied archaeologically, it is difficult to name a

25 Graham, "Mission Archaeology," Panich, "Mission Archaeology."

26 Bonnie G. McEwan, Spanish Missions of La Florida (Gainesville: University Press of Florida, 1993); and chapters in David Hurst Thomas, ed., Columbian Consequences, Volume 1: Archaeological and Historical Perspectives on the Spanish Borderlands West (Washington, DC: Smithsonian Institution Press, 1989); Thomas, ed., Columbian Consequences, Volume 2: Archaeological and Historical Perspectives on the Spanish Borderlands East (Washington, DC: Smithsonian Institution Press, 1990); Thomas, ed., Columbian Consequences, Volume 3: Spanish Borderlands in Pan-American Perspective (Washington, DC: Smithsonian Institution Press, 1991). Also see Kent G Lightfoot, Indians, Missionaries and Merchants the Legacy of Colonial Encounters on the California Frontiers (Berkeley: University of California Press, 2004); Christopher M. Stojanowski, Mission Cemeteries, Mission Peoples Historical and Evolutionary Dimensions of Intracemetery Bioarchaeology in Spanish Florida (Gainesville: University Press of Florida, 2013); Lee M. Panich and Tsim D. Schneider, "Expanding Mission Archaeology: A Landscape Approach to Indigenous Autonomy in Colonial California," Journal of Anthropological Archaeology 40 (2015): 48-58. 
single well-known Jesuit site that can be held up as an outstanding example. ${ }^{27}$ Moreover, many well-known sources are not methodologically relevant to contemporary field and collections projects. One explanation referenced earlier is that language barriers divide archaeological studies into different silos, preventing comparative research, and that the material for regional studies remains trapped in gray literature, or in artifact collections that have yet to be studied. ${ }^{28}$ Furthermore, archaeologists might dig at a site that Jesuits had owned and managed, or visited during their mission circuits, but are unable to identify the "Jesuit" period of occupation with certainty, or recover a "Jesuit" object such as an iconographic ring or crucifix.

We also question whether there is a "silencing of the past" at work, to borrow the words of anthropologist Michel Trouillot. ${ }^{29}$ The Jesuits themselves have been more embarrassed than interested in topics like slavery, as Thomas Murphy recounts in his 2001 study. ${ }^{30}$ Readers may be aware of recent reconciliation efforts made by Georgetown University toward descendants of enslaved Africans sold by the Maryland province in 1838 , and the recently published special issue of the Journal of Jesuit Studies entitled "Jesuits and Slavery."31 Although histories of enslavement have never been hidden per se, with records readily available in the Maryland Province Archives and publications like the Woodstock Letters, recent activism raised important questions about archival accessibility and the debts that the Society of Jesus owes to the descendants of the persons they enslaved. Projects like the Georgetown Slavery Archive (slaveryarchive.georgetown.edu) and the Slavery, History, Memory, and Reconciliation Project provide newly accessible data on the lives of enslaved Africans at Jesuit plantations and colleges, stimulating new interest in identifying and interpreting slave quarter sites on these properties. ${ }^{32}$ These projects-like several of the studies featured in this issue-also adopt a new approach to Jesuit sites

27 Anglophone archaeologists may be familiar with McNaspy's treatment of Jesuit reductions in Paraguay. McNaspy, "Archaeology of the Paraguay Reductions."

28 Nimmo, "Approaching Archaeological Museum Collections."

29 Michel-Rolph Trouillot, Silencing the Past: Power and the Production of History (Boston: Beacon Press, 1995).

30 Murphy, Jesuit Slaveholding in Maryland.

31 Adam Rothman, "The Jesuits and Slavery," Journal of Jesuit Studies 8, no. 1 (2021): 1-10, doi:10.1163/22141332-08o1Poo1.

32 Kelly L. Schmidt, "A National Legacy of Enslavement: An Overview of the Work of the Slavery, History, Memory, and Reconciliation Project," Journal of Jesuit Studies 8, no. 1 (2021): 81-107, doi:10.1163/22141332-08o1Poo5. Julia A. King, Christopher L. Coogan, and Scott M. Strickland, "Archaeological Investigations at Newtowne Neck State Park, Formerly Newtown Manor, Compton, Maryland," Report prepared for Maryland Department of Natural Resources, Maryland Heritage Areas Authority (St. Mary's City, MD: St. Mary's College of Maryland, 
by highlighting the lives and experiences of the enslaved, whereas traditional histories and archaeological studies have focused almost exclusively on Jesuits themselves.

The study of American Indian mission sites also presents possibilities as well as ethical challenges. In the United States, many of the devotional artifacts used to associate American Indian archaeological sites with Jesuit missions come from burial contexts that were excavated prior to the passage of Native American Graves Protection and Repatriation Act in 1990. ${ }^{33}$ American Indian communities have a vested interest in the repatriation and reburial of these human remains and funerary objects as a way of regaining sovereignty and healing from anthropology and archaeology's violent legacies. Some communities, however, marshal the archaeology of Jesuit sites in order to provide evidence of their long-term history. Beaupré's article captures this process as it is an ongoing issue with Abenakis seeking sovereignty in Vermont. Moreover, Catholic descendant and stakeholder groups have a strong interest in the narrative history of Jesuit sites. The question that remains to be resolved is how historical archaeologists can identify and carry out ethical best practices when working on Jesuit sites, particularly when numerous descendant and stakeholder groups have a vested interest in their history. Ethical practices that consider the relevance of the past for people in the present must be a hallmark of future archaeologies of Jesuit sites in the Americas.

2017); Laura E. Masur, "Priestly Plantations: An Archaeology of Capitalism and Community in British North America" (unpublished PhD diss., Boston University, 2019).

33 The Native American Graves Protection and Repatriation Act (NAGPRA) of 1990 both protects Native American burials and funerary objects on federally managed land and establishes a system for the repatriation and reburial of human remains and grave goods excavated prior to the law's passage. 